\title{
Treatment and outcome of fibroepithelial ureteral polyps: A systematic literature review
}

\author{
Dina J. Ludwig, MD; ${ }^{*}$ Karel T. Buddingh, MD, PhD; Jan J.M. Kums, MD; ${ }^{\dagger}$ René F. Kropman, MD, PhD; \\ Hossain Roshani, MD, PhD; ${ }^{*}$ Willem H. Hirdes, $M D^{\dagger}$
}

*Department of Urology, Haga Teaching Hospital, The Hague, The Netherlands; 'Department of Urology, Isala Clinics, Zwolle, The Netherlands

Cite as: Can Urol Assoc J 2015;9(9-10):E631-7. http://dx.doi.org/10.5489/cuai.2878 Published online September 9, 2015.

\section{Abstract}

Introduction: Fibroepithelial polyps of the ureter are rare. Cases and small series are reported in the literature. The treatment of choice, outcome and appropriate follow-up regimen remain unclear.

Methods: We conducted a systematic literature review of papers reporting fibroepithelial polyps of the ureter in adult patients. Articles published before 1980 were excluded.

Results: The search yielded 144 papers, of which 68 met the inclusion criteria. A reference scan from the included 68 yielded an additional 7 new articles. In total, our study included 75 articles $(68+7)$. A total of 134 patients were described. Most patients had a single lesion (range: 1-10). The median length of the polyp was $4.0 \mathrm{~cm}$ (range: $0.4-17.0$ ). The percentage of polyps resected endoscopically increased from 0\% before 1985 to $67 \%$ after 2005 . Two perioperative complications were reported in 72 procedures (2.8\%): a deep venous thrombosis and a case of mesenteric lymphadenopathy. Both of these occurred after open surgery. Follow-up data were available for 57 patients. The median follow-up was 12 months (range: $1-180)$. Four patients $(7.0 \%)$ developed recurrent complaints: 2 had urinary stones, 1 had a ureteral stricture and 1 had recurrence of the polyp. Three of these events followed endoscopic resection, and occurred within a year after the procedure. Conclusion: Endoscopic resection of fibroepithelial polyps seems to be safe and effective. It is minimally invasive and should be considered the gold standard where endoscopic expertise is available. We advise follow-up imaging by computed tomographic intravenous urography after 3 months and ultrasound after 1 year to detect late complications.

\section{Introduction}

Fibroepithelial polyps of the ureter are rare benign lesions of the urinary tract. They are non-epithelial benign tumours of mesodermal orgin, a category that also includes leiomyomas, fibromas, neurofibromas and lymphangiomas. They are derived from mesenchymal tissue, in contrast with malignant transitional cell and squamous cell tumours which are derived from the epithelium. ${ }^{1}$ In general, benign tumours account for $20 \%$ of all ureteral tumours. ${ }^{2}$

Most urologists will only infrequently encounter patients with a fibroepithelial polyp. They rely on the medical literature as guidance for treatment and follow-up. However, most published papers are case reports or describe small patient series. One larger review dates from 1980 and is outdated in the era of flexible ureteroscopy. ${ }^{3}$ Several recent review articles focus on fibroepithelial polyps in children. ${ }^{4,5}$ The aim of this study was to provide a systematic overview of the literature on fibroepithelial polyps in adult patients. In this way, evidence-based choices can be made for treatment and follow-up of patients with this condition.

\section{Methods}

A systematic literature review was performed of fibroepithelial polyps of the ureter. We conducted a search of the PubMed, EMBASE and Cochrane Library databases for English language literature published between January 1980 and January 2014. Papers published before 1980 were disregarded as they date from an era before the widespread use of (flexible) ureteroscopy. The search terms used were 'fibro-epithelial OR fibroepithelial AND ureter OR ureteral.'

Papers were included if they presented one or more patients aged 18 years or older with one or more fibroepithelial polyps of the ureter. Patients with only polyps in the renal pyelum or only in the bladder were excluded. The reference lists of the selected articles were then searched for more papers that met the inclusion criteria.

Statistical analysis was done using SPSS 17.0 for windows (SPSS Inc, Chicago, IL). Exploratory univariate analysis 
was performed to identify factors influencing the choice for endoscopic or open resection of polyps. The Pearson Chi Square test was used to compare proportions. The independent samples t-test was used to compare normally distributed continuous variables. The Mann-Whitney U-test was used to compare continuous variables that were not normally distributed.

\section{Results}

\section{Search results and study characteristics}

The primary search yielded 144 results. Of these 144 papers, 7 concerned different conditions other than fibroepithelial polyps or were review papers. Children only were described in 47 articles and no distinction was made in another 2 papers. Eight papers described fibroepithelial polyps in other locations than the ureter (urethra, bladder and renal pelvis). Three papers were veterinary studies and 9 papers were only published as abstracts (presentations at conferences). Therefore, of the 144 papers, we excluded 76 .

The reference lists of the remaining 68 articles were searched for additional papers of interest. This search yielded another 7 studies, which were included. In total, 75 articles met the inclusion criteria (Fig. 1). ${ }^{1-3,6-77}$ Most papers (56/75) presented a single patient. The largest series was reported by Williams and colleagues ${ }^{67}$ and included 15 patients. Together, the 75 papers described 134 adult patients with one or more fibroepithelial polyps of the ureter.

\section{Patient and polyp characteristics}

Of the 131 patients with available data, 71 were female (55.9\%). Most patients presented with flank pain and/or hematuria (Table 1). Intravenous ureterography was the most frequently used imaging modality (84.4\%). Most patients had only 1 polyp (86.5\%), but the maximum reported was 20 polyps in a single patient (both ureters were affected). The median size of the polyps was $4.0 \mathrm{~cm}$ (range: 0.4-17.0). Polyps were evenly distributed among the left and right ureter, with a few patients with bilateral polyps. Polyps were encountered over the entire ureter, but most frequently in the proximal ureter. The polyp caused hydronephrosis in $41.7 \%$ of patients. Urinary tract stones were present in $20.8 \%$ of patients and concomitant urological abnormalities, such as duplicated urinary tracts, were found in $7.0 \%$ (Table 1 ). A coincidental transitional cell carcinoma, located on the epithelial of the fibroepithelial polyp, was reported in one of the patients in this review. ${ }^{73}$

\section{Treatment, outcome and follow-up}

Mode of treatment was reported for 113 patients (Table 2). Two patients were initially managed conservatively. One of these patients was being treated for advanced gastric cancer and had over 20 fibroepithelial polyps in both ureters. ${ }^{32}$ The authors deemed it impossible to resect all of them without damaging the ureter. Therefore, the patient received bilateral nephrostomy catheters. No follow-up was reported. The other patient returned 11 months later with recurrent flank

Table 1. Patient characteristics

\begin{tabular}{|c|c|c|}
\hline & & $\begin{array}{c}\text { Articles with } \\
\text { available data } \\
\text { (total }=131) \dagger\end{array}$ \\
\hline Age, years (median; min-max) & $38(18-76)$ & 126 \\
\hline Female gender & $71(55.9 \%)$ & 127 \\
\hline No. polyps & & 104 \\
\hline 1 & $90(86.5 \%)$ & \\
\hline 2 & $4(3.8 \%)$ & \\
\hline 3 & $5(4.8 \%)$ & \\
\hline$\geq 4$ & $5(4.8 \%)$ & \\
\hline Size, cm, median (range) & $4.0(0.4-17.0)$ & 104 \\
\hline Side of polyp distribution & & 108 \\
\hline Left & $55(50.9 \%)$ & \\
\hline Right & $50(46.3 \%)$ & \\
\hline Both & $3(2.8 \%)$ & \\
\hline Level of polyp distribution & & 121 \\
\hline Proximal ureter & $55(45.5 \%)$ & \\
\hline Middle ureter & $25(20.7 \%)$ & \\
\hline Distal ureter & 41 (33.9\%) & \\
\hline Symptoms & & 116 \\
\hline Flank pain & $77(66.4 \%)$ & \\
\hline Hematuria & $50(43.1 \%)$ & \\
\hline (Recurrent) UTI & $5(4.3 \%)$ & \\
\hline Other & $3(2.6 \%)$ & \\
\hline No symptoms & $7(6.0 \%)$ & \\
\hline Imaging & & 109 \\
\hline Ultrasound & $23(21.1 \%)$ & \\
\hline IVU & $92(84.4 \%)$ & \\
\hline CT & $35(32.1 \%)$ & \\
\hline RPG/RUG & $42(38.5 \%)$ & \\
\hline Hydronephrosis & $40(41.7 \%)$ & 96 \\
\hline Intussusception & $7(7.3 \%)$ & 96 \\
\hline Urolithiasis & $21(20.8 \%)$ & 101 \\
\hline Other urological abnormalities & & 100 \\
\hline UPJ stenosis & $3(3.0 \%)$ & \\
\hline Duplicated upper tract & $2(2.0 \%)$ & \\
\hline Cystic ureteritis & $1(1.0 \%)$ & \\
\hline Ureterocele & $1(1.0 \%)$ & \\
\hline \multicolumn{3}{|c|}{$\begin{array}{l}\text { tOf the total } 134 \text { adult patients, } 3 \text { did not have available data. UTI: urinary tract infection; } \\
\text { IVU: intravenous urography; CT: computed tomography; RPG: retrograde pyelography; } \\
\text { RUG: retrograde ureterography; UPJ: ureteropelvic junction. }\end{array}$} \\
\hline
\end{tabular}


pain and hematuria and was then treated by endoscopic resection. $^{\text {? }}$

The method of endoscopic resection was further specified in 44 cases. Most polyps were resected using electrocautery or Holmium:YAG laser (Table 2). The remaining patients were treated by polypectomy via ureterotomy, partial ureterectomy or nephro-ureterectomy. The proportion of patients treated by endoscopic resection increased from none before 1985 to $66.7 \%$ after 2005 (Fig. 2). Two perioperatieve complications were reported ${ }^{33,40}$ in 72 procedures $(2.8 \%)$ : one deep venous thrombosis ${ }^{40}$ and one case of mesenteric lymphadenopathy. ${ }^{33}$ Both of these occurred after open surgery.

Outcome data were available of 57 patients. Four patients developed recurrent symptoms $(7.0 \%) ; 3$ of these patients had initially been treated endoscopically and 1 by surgical resection. Two of these patients had recurrent urinary tract stones..$^{9,13}$ One had recurrent or residual growing polyp (after an incomplete initial resection). ${ }^{17}$ One patient had a ureteric stricture. ${ }^{56}$ Three of these late complications occurred within 1 year and a case of urolithiasis occurred after 3 years.

Exploratory univariate analysis was performed to investigate which factors may have influenced urologists in their choice for endoscopic or surgical resection of the polyp (Table 3). Polyps that were endoscopically resected were less likely to be in the proximal ureter, more likely to have concomitant urolithiasis, and more likely to have been operated after 2000. Larger polyps were more likely to have been removed surgically by open approach. However, successful ureteroscopic resection of polyps up to $16 \mathrm{~cm}$ was reported. ${ }^{56}$

\begin{tabular}{|c|c|c|}
\hline & Value & $\begin{array}{c}\text { Cases with data } \\
\text { available (total }=134)\end{array}$ \\
\hline Treatment & & 113 \\
\hline Conservative & $2(1.8 \%)$ & \\
\hline Endoscopic resection & $49(43.4 \%)$ & \\
\hline Ureterotomy & $26(23.0 \%)$ & \\
\hline Partial ureterectomy & $26(23.0 \%)$ & \\
\hline Nephro-ureterectomy & $10(8.8 \%)$ & \\
\hline $\begin{array}{l}\text { Method endoscopic } \\
\text { resection }\end{array}$ & & 44 \\
\hline Holmium:YAG laser & $16(36.4 \%)$ & \\
\hline Electrocautery & $23(52.3 \%)$ & \\
\hline Mechanical & $5(11.4 \%)$ & \\
\hline $\begin{array}{l}\text { Perioperative } \\
\text { complications }\end{array}$ & $2(2.8 \%)$ & 72 \\
\hline Follow-up & & 134 \\
\hline Until discharge only & 77 (57.5\%) & \\
\hline$\leq 6$ months & $17(12.7 \%)$ & \\
\hline 7 months-1 year & $13(9.7 \%)$ & \\
\hline $1-2$ years & $12(9.0 \%)$ & \\
\hline $2-5$ years & $12(9.0 \%)$ & \\
\hline$>5$ years & $3(2.2 \%)$ & \\
\hline Outcome & & 57 \\
\hline Complaint free & $53(93.0 \%)$ & \\
\hline $\begin{array}{l}\text { Recurrent or remnant } \\
\text { stones }\end{array}$ & $2(3.5 \%)$ & \\
\hline Ureteric stricture & $1(1.8 \%)$ & \\
\hline Recurrent polyp & $1(1.8 \%)$ & \\
\hline
\end{tabular}

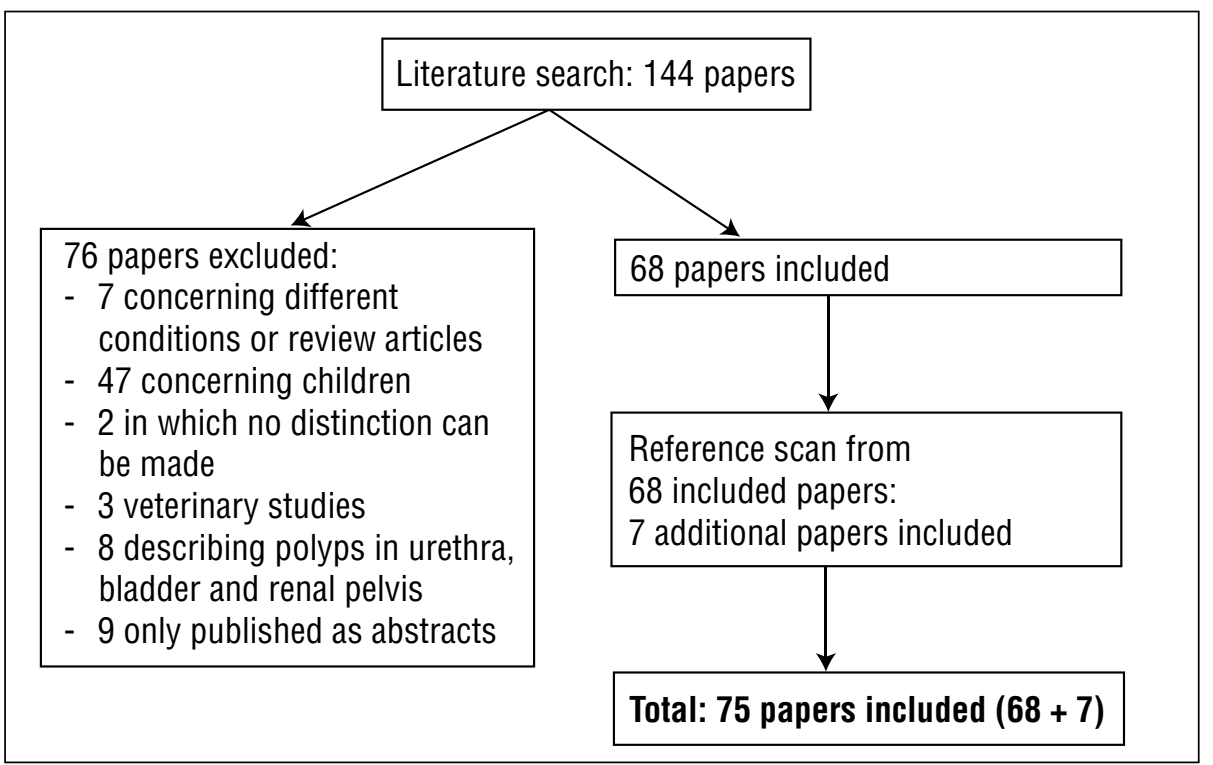

Fig. 1. Flow chart of included papers. 


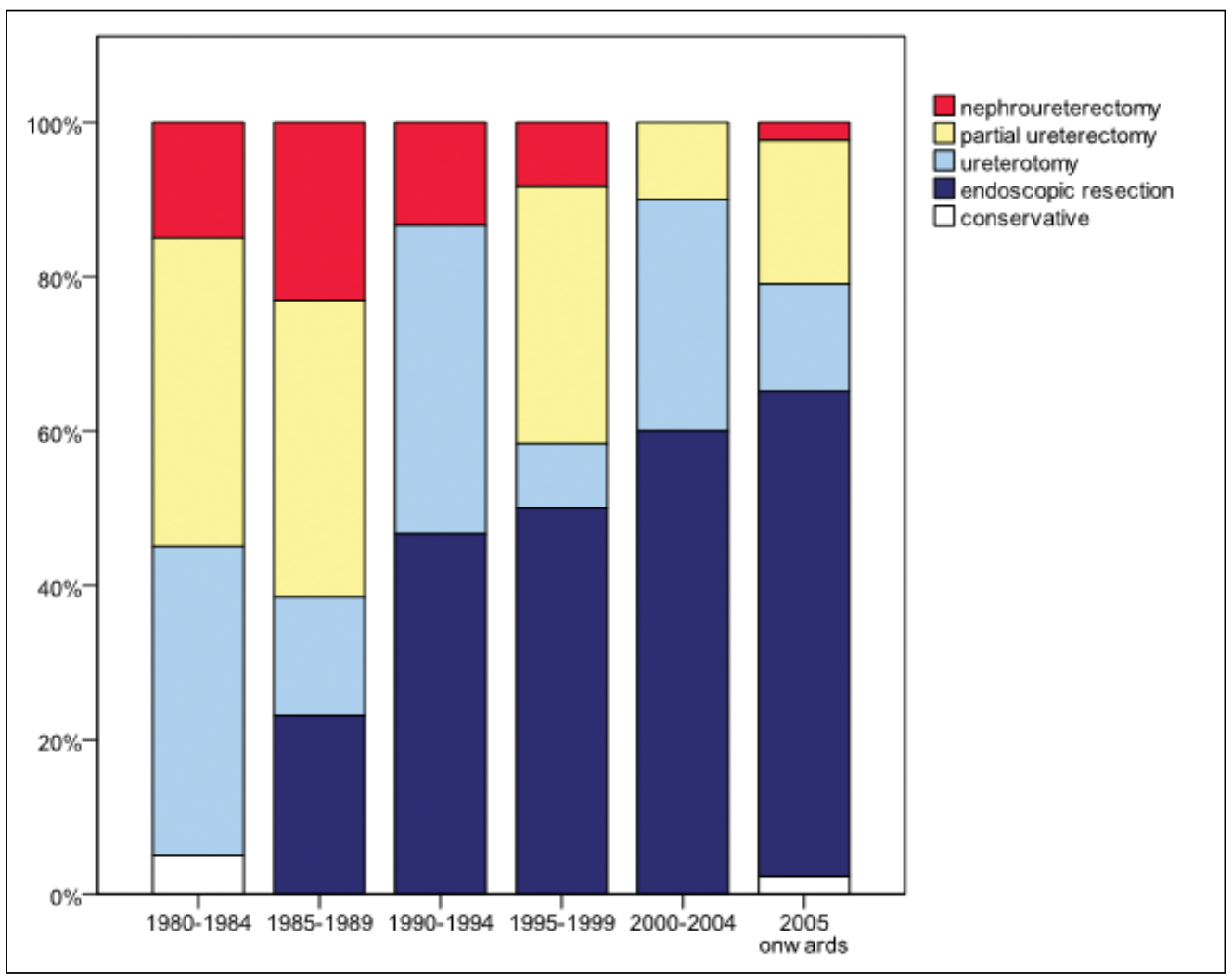

Fig. 2. Trends in treatment of fibroepithelial polyps between 1980 and 2014.

\section{Discussion}

We have provided a comprehensive review of ureteral fibroepithelial polyp described in the English language literature since 1980. Ureteroscopic resection has become the most performed method of treatment. According to data, it is safe and effective. As the least invasive type of surgery, it should be considered the gold standard.

In 1980, Debruyne and colleagues analyzed 112 patients with fibroepithelial polyps treated since $1950 .{ }^{3}$ Most complaints were flank pain and hematuria. The authors also describe predominance in male patients and a slight preference for the left ureter. These observations are not supported by the data presented in our review. This may be explained by the fact that Debruyne and colleagues included children in their review. Having been written in the pre-ureteroscopy era, the paper by Debruyne and colleagues advised that surgical resection of the polyp is always necessary. They noted that although local resection is preferred, $37 \%$ of patients underwent nephro-ureterectomy instead. Over the past 30 years, this percentage has decreased to almost zero (Fig. 2).

By exploratory univariate analysis we identified possible factors associated with urologists' choice for surgical rather than endoscopic resection. Besides operation after the year 2000, smaller polyp size, concomitant stones and distal location in the ureter were associated with endoscopic resection. The fact that proximal polyps were more likely surgically resected may be explained by the technical difficulty in achieving adequate endoscopic exposure of the polyp in that part of the ureter. Although larger polyps were more likely to be surgically resected, polyps up to $16 \mathrm{~cm}$ were successfully removed endoscopically. Therefore, size of the polyp should not be a contraindication for endoscopic resection.

Concomitant transitional cell carcinoma was reported in $1 / 108^{3,78}$ cases described by Debruyne et al and in $1 / 134$ patients in the current review. Considering the small chance of concomitant malignancy, we advise a form of endoscopic treatment that allows pathologic examination of the resected polyp. If malignancy is found, decision for nephro-ureterectomy or follow-up should be made by a multidisciplinary oncology team taking also the resection margins and grade of the tumour into account. Laser ablation of (parts of) the polyp may be considered after taking representative biopsies for pathological analysis.

In their review article, Debruyne and colleagues reported no recurrence or late complications. ${ }^{3}$ The current study revealed 4 patients $(7.0 \%)$ who developed late complaints: two with remnant or recurrent stones, 1 ureteral stricture and 1 with recurrent polyps. These complications warrant 


\begin{tabular}{|c|c|c|c|}
\hline Factor & $\begin{array}{l}\text { Endoscopic } \\
\text { group }\end{array}$ & Surgery group & $p$ value \\
\hline Female gender & $31 / 47(66.0 \%)$ & $32 / 60(53.3 \%)$ & $0.218^{a}$ \\
\hline Age & $42 \pm 16$ years & $36 \pm 13$ years & $0.039^{b}$ \\
\hline Polyp size & $3.0(0.5-16.0)$ & $6.0(0.4-17)$ & $0.009^{c}$ \\
\hline $\begin{array}{l}\text { Location proximal } \\
\text { ureter }\end{array}$ & $11 / 44(25.0 \%)$ & $32 / 59(54.2 \%)$ & $0.003^{a}$ \\
\hline $\begin{array}{l}\text { Concomitant } \\
\text { urolithiasis }\end{array}$ & $13 / 39(33.3 \%)$ & $8 / 59(13.6 \%)$ & $0.020^{\mathrm{a}}$ \\
\hline Published after 2000 & $34 / 50(68.0 \%)$ & $18 / 61(29.5 \%)$ & $<0.001^{\mathrm{a}}$ \\
\hline
\end{tabular}

follow-up imaging studies. As 3 of the 4 events occurred within a year of the initial resection, it is advisable to conduct follow-up imaging within 1 year (i.e., after 3 and 12 months). Some authors advise intensive follow-up-regimen with frequent urinalysis, ultrasound and intravenous urography (IVU) or computed tomography (CT) in the first years after surgery. ${ }^{36,56,68}$ Considering the pattern of recurrent complaints (mostly within the first year) and the benign nature of the lesion, it is our opinion that a CT-IVU after 3 months and ultrasound of the urinary tract after 1 year are sufficient follow-up methods.

The pathogenesis of fibroepithelial polyps remains uncertain. Factors, such as obstruction, trauma, irritation, infection, exogenous carcinogens, hormonal imbalance, and allergy, have been proposed as causative agents. Stones may cause chronic irritation of the ureteral wall, with or without urinary infection, but their actual role is uncertain. ${ }^{5}$

The association with urolithiasis $(20.8 \%$ in this study) could be explained in several ways. Firstly, the altered anatomy with ureteral polyps could promote the formation of stones. Secondly, urolithiasis is more likely to become symptomatic if there is already partial obstruction by a ureteral polyp. Thirdly, the presence of stones and the associated irritation of the urothelium could cause the formation of polyps. To our knowledge there is no apparent reason why chronic irritation of the ureter wall leads to transitional cell carcinoma in some patients and fibroepithelial polyps in others.

Although possibly even more rare than in adults, fibroepithelial polyps are occasionally found in the pediatric population. They account for $0.5 \%$ of ureteropelvic junction (UPJ) obstructions in children. ${ }^{79}$ Pediatric polyps are often located in the UPJ and upper ureter $(73.3 \%) ;{ }^{80}$ only a handful of cases are reported more distally in the ureter. ${ }^{81}$ In contrast to the adult population, there seems to be a male preponderance $(89 \%)^{79}$ and a more frequent involvement of the left ureter $(67 \%)$. Preoperative diagnosis of ureteral polyps in children is challenging because of the small lumen of the ureter. Malignant ureteral transitional cell tumours have not been reported in children. ${ }^{4,80}$ Ultrasonography is still the first choice for the diagnosis, because it is harmless and convenient. ${ }^{79,80}$ There are however insufficient data to estimate the specificity of ultrasound for this condition.

Our paper is the most complete overview of the treatment and outcome of ureteral fibroepithelial polyps in adults; however, it has its limitations. An important limitation is that we relied on data from case reports and small patient series. This made our results susceptible to publication bias. Publication is likely to be biased towards larger and multiple polyps. Therefore, the size and the number of polyps reported in this study were probably larger than the average in clinical practice. Regarding the complication rate, it could be hypothesized that there was a publication bias towards uncomplicated procedures. Another limitation of this study is that it does not include papers reported in languages other than English (although if we had included these non-English articles, the number of patients would have likely increased by a fraction). Moreover, it is unlikely that the general conclusions would have been affected.

\section{Conclusion}

Endoscopic resection is a safe and effective treatment for fibroepithelial polyps of the ureter, and should be considered the gold standard where endoscopic expertise is available. Based on the pattern of late complications reported in literature, we advise control CT-IVU at 3 months and control ultrasound after 1 year to detect possible recurrence or stricture.

Competing interests: The authors declare no competing financial or personal interests.

This paper has been peer-reviewed.

\section{References}

1. Ugras $\mathrm{S}$, Odabas 0 , Aydin $\mathrm{S}$, et al. Fibroepithelial polyp of the ureter associated with an adjacent ureteral calculus. Int Urol Nephrol 1997;29:543-9. http://dx.doi.org/10.1007/BF02552199

2. Franco I, Choudhury $M$, Eshghi $M$, et al. Fibroepithelial polyp associated with congenital ureteral diverticulum: Report of 2 cases. J Urol 1988; 140:598-600.

3. Debruyne FM, Moonen WA, Daenekindt AA, et al. Fibroepithelial polyp of ureter. Urology 1980;16:355-9. http://dx.doi.org/10.1016/0090-4295(80)90137-5

4. Cassar DE, Joseph VT, Sherwood W. Fibroepithelial polyps causing ureteropelvic junction obstruction in children: A case report and review article. Eur J Pediatr Surg 2007;17:142-6. http://dx.doi. org/10.1055/s-2007-965014

5. Romesburg JW, Stein RJ, Desai MM, et al. Treatment of child with bilateral ureteropelvic junction obstruction due to fibroepithelial polyps and review of the literature. Urology 2009;73: 929.e9-11. http://dx.doi. org/10.1016/i.urology.2008.04.040

6. Anderstrom C, Hansson HA, Johansson SL. Scanning electron microscopy of upper urinary tract tumors. Cancer 1984;54:876-81. http://dx.doi.org/10.1002/1097-0142(19840901)54:5<876::AIDCNCR2820540520>3.0.C0;2-F

7. Bahnson RR, Blum MD, Carter MF. Fibroepithelial polyps of the ureter. J Urol 1984;132:343-4.

8. Baltogiannis D, Kafetsoulis A, Giannakis D, et al. Fibroepithelial polyp of distal ureter with periodic prolapse into bladder. Urol Int 2008;80:338-40. http://dx.doi.org/10.1159/000127355 
Ludwig et al.

9. Bargnesi DS, Abaza R, Selman SH. Laparoscopic management of extensive ureteral fibroepithelial polyps. Can J Urol 2009;16:4936-8.

10. Bellin MF, Springer 0, Mourey-Gerosa I, et al. CT diagnosis of ureteral fibroepithelial polyps. Eur Radiol 2002;12:125-8. http://dx.doi.org/10.1007/s003300100933

11. Bolton D, Stoller ML, Irby P III. Fibroepithelial ureteral polyps and urolithiasis. Urology 1994;44:582-7. http://dx.doi.org/10.1016/S0090-4295(94)80066-9

12. Brummeis $W$, Fritsche HM, Huber $E$, et al. A patient with fibroepithelial polyp of the ureter-a rare condition mimicking malignancy: a case report. Case Rep Urol 2012;2012:901693. http://dx.doi. org/10.1155/2012/901693

13. Carey RI, Bird VG. Endoscopic management of 10 separate fibroepithelial polyps arising in a single ureter. Urology 2006;67:413-5. http://dx.doi.org/10.1016/j.urology.2005.08.020

14. Chang HH, Ray P, Ockuly E, et al. Benign fibrous ureteral polyps. Urology 1987;30:114-8. http:// dx.doi.org/10.1016/0090-4295(87)90174-9

15. Chou CP, Wu TT, Levenson RB, et al. Ureteral fibroepithelial polyp diagnosed preoperatively on virtual CT ureteroscopy. Abdom Imaging 2007;32:421-3. http://dx.doi.org/10.1007/s00261-006-9084-1

16. Coloma del Peso A, Bocardo Fajardo G, Teba del Pino F, et al. Endoscopic treatment of a giant fibroepithelial polyp of the ureter. Arch Esp Urol 2010;63:305-8.

17. Cooper CS, Hawtrey CE. Fibroepithelial polyp of the ureter. Urology 1997;50:280-1. http://dx.doi. org/10.1016/50090-4295(97)00221-5

18. Faerber $\mathrm{GJ}$, Ahmed MM, Marcovich R, et al. Contemporary diagnosis and treatment of fibroepithelial ureteral polyp. J Endourol 1997;11:349-51. http://dx.doi.org/10.1089/end.1997.11.349

19. Fiorelli C, Durval A, Di Cello V, et al. Ureteral intussusception by a fibroepithelial polyp. J Urol 1981;126:110-2

20. Gana BM, Evans AT, Weaver JP. Fibroepithelial polyp of the ureter. Br J Urol 1993;72:660-1. http:// dx.doi.org/10.1111/j.1464-410X.1993.tb16232.x

21. Giannakopoulos X, Papanikolaou A, Chambilomatis P, et al. Benign fibroepithelial ureteral polyps. Report of 3 cases. Minerva Urol Nefrol 1994;46:255-9.

22. Harvin HJ. Ureteral fibroepithelial polyp on MDCT urography. AJR Am J Roentgenol 2006;187:W434-5. http://dx.doi.org/10.2214/AJR.05.1631

23. Hasegawa Y, Mita K, Ueki T, et al. Retroperitoneoscopic treatment of ureteral invagination caused by a long fibroepithelial polyp protruding into the bladder: Report of a case. Surg Today 2011;41:1117-21. http://dx.doi.org/10.1007/s00595-010-4422-x

24. Hollander JB, Diokno AC, Devendra $G$. Endoscopic management of a large distal ureteral polyp as an outpatient. J Urol 1987;172A.

25. Jin XB, Meng HL, Zhang YD, et al. Laparoscopic treatment of a massive fibroepithelial polyp accompanied by ureteral intussusception. Chin Med J (Engl) 2011;124:3436-9.

26. Karmo BT, Lim K, Santucci RA, et al. Robot-assisted right ureteral polypectomy: A case report. Can Urol Assoc J 2013;7:E426-9. http://dx.doi.org/10.5489/cuaj.1392

27. Kawachi Y, Ishi K. Inverted transitional cell carcinoma of the ureter. Int I Urol 1996;3:313-5. http:// dx.doi.org/10.1111/j.1442-2042.1996.tb00543.x

28. Kiel $H$, Ullrich $T$, Roessler $W$, et al. Benign ureteral tumors. Four case reports and a review of the literature. Urol Int 1999;63:201-5. http://dx.doi.org/10.1159/000030448

29. Kijvikai K, Maynes U, Herrell SD. Laparoscopic management of large ureteral fibroepithelial polyp. Urology 2007;70:373-7. http://dx.doi.org/10.1016/i.urology.2007.05.011

30. Kim H, Kim DK, Lee SJ, et al. Fibroepithelial ureteral polyp-a case report; endoscopic removal of large ureteral polyp. J Korean Med Sci 1996;11:80-3. http://dx.doi.org/10.3346/ikms.1996.11.1.80

31. Kim HJ, Lim JW, Lee DH, et al. Differentiation of malignant from benign distal ureteral obstructions: Assessment using transrectal and color Doppler ultrasonography. J Ultrasound Med 2007;26:1129-36.

32. Kim SO, Youn CW, Kang TW, et al. Multiple, bilateral fibroepithelial polyps causing acute renal failure in a gastric cancer patient. J Korean Med Sci 2010;25:644-6. http://dx.doi.org/10.3346/ jkms.2010.25.4.644

33. Klezl P, Stanc 0 , Richterova R, et al. Benign fibroepithelial polyp of the ureter. Cent European I Urol 2013;66:168-71

34. Kumar A, Das SK, Trivedi S, et al. Genito-urinary polyps: Summary of the 10-year experiences of a single institute. Int Urol Nephrol 2008;40:901-7. http://dx.doi.org/10.1007/s1 1255-008-9391-2

35. Lai TK, Chung $\mathrm{CH}$, Chin AC, et al. Magnetic resonance imaging for ureteral fibroepithelial polyp. Hong Kong Med J 2008;14:408-10.

36. Lam JS, Bingham JB, Gupta M. Endoscopic treatment of fibroepithelial polyps of the renal pelvis and ureter. Urology 2003;62:810-3. http://dx.doi.org/10.1016/S0090-4295(03)00691-5

37. Ledor K, Mieza M, Ledor S, et al. Multicentric fibroepithelial ureteral polyp. Urol Radiol 1982;4:259-61 http://dx.doi.org/10.1007/BF02924059

38. Lore CE, Mobley J, Zaslau S. Fibroepithelial polyp of the ureter presenting incidentally in a patient with a diverticular abscess. W V Med J 2004;100:70-1.
39. Momenzadeh A, Sarrafzadeh F, Nourbala MH, et al. Giant ureteral fibroepithelial polyp presenting as a bladder mass resected ureteroscopically: A case report. Nephrourol Mon 2013;5:706-8. http://dx.doi. org/10.5812/numonthly.4933

40. Murshidi MS. Calculous disease and its relationship to fibroepithelial polyps of the renal pelvis and ureter. Acta Urol Belg 1988;56:47-54.

41. Muslumanoglu AY, Karaman MI, Ergenekon E, et al. A distal ureteral fibrous polyp and the role of ureteroscopic resection in its management. J Endourol 1994;8:199-201. http://dx.doi.org/10.1089/end. 1994.8.199

42. Naucler J, Johansson SL, Nilson AE, et al. Fibroepithelial polyp of the ureter. Scand J Urol Nephrol 1983;17:379-83. http://dx.doi.org/10.3109/00365598309182151

43. Ney C, Yerubandi S, Levy J. Fibroepithelial polyps of ureter. Urology 1983;21:393-5. http://dx.doi. org/10.1016/0090-4295(83)90161-9

44. Niu JR, Rong S, Ji ZG, et al. Bilateral ureteral fibroepithelial polyps: A case report. Chin Med Sci J 2012;27:125-6

45. Oesterling JE, Liu HY, Fishman EK. Real-time, multiplanar computerized tomography: A new diagnostic modality used in the detection and endoscopic removal of a distal ureteral fibroepithelial polyp and adiacent calculus. J Urol 1989; 142:1563-6.

46. Patheyar V, Venkatesh SK, Siew EP, et al. MR imaging features of fibroepithelial ureteral polyp in a patient with duplicated upper urinary tract. Singapore Med J 2011;52:e45-7.

47. Piovesan AC, Torricelli $F C M$, Borges $L L$, et al. Ureteral fibroepithelial polyps in a pregnant woman: Case report. Sao Paulo Med I 2009;127:238-40. http://dx.doi.org/10.1590/S1516-31802009000400010

48. Png JCD, Tung KH. Intussusception of a ureteric polyp causing acute hydronephrosis. Br J Urol 1995;6:8012. http://dx.doi.org/10.1111/i.1464-410X.1995.tb07400.x

49. Psihramis KE, Hartwick W. Ureteral fibroepithelial polyp with positive urinary cytology. Urology 1993;41:387-91. http://dx.doi.org/10.1016/0090-4295(93)90606-B

50. Salas $M$, Gelet A, Martin $X$, et al. Endourological management of fibroepithelial polyps. Eur Urol 1991;19:178-80.

51. Schiotz HA. Fibroepithelial polyp of the ureter. A case history and discussion. Acta Obstet Gynecol Scand 1990;69:267-8. http://dx.doi.org/10.3109/00016349009028692

52. Seckin B, Bedir S, Sumer F, et al. Fibroepithelial polyp of the ureter in a young adult. J Ankara Medical School 2003;25:161-4. http://dx.doi.org/10.1501/ims_0000000059

53. Sharma NK, Stephenson RN, Tolley DA. Endoscopic management of fibroepithelial polyps in the ureter. $\mathrm{Br}$ J Urol 1996;78:131-2. http://dx.doi.org/10.1046/j.1464-410X.1996.12927.x

54. Sinha RK, Jindal T, Kamal MR, et al. Fibroepithelial polyp of the ureter. BMJ Case Rep 2013;2013.

55. Stukart RA, van Haga JJ, Bruijnes E. Fibroepithelial ureteral polyps. Urol Int 1984;39:336-8. http:// dx.doi.org/10.1159/000281006

56. Sun $Y, X \cup C$, Wen $X$, et al. Is endoscopic management suitable for long ureteral fibroepithelial polyps? J Endourol 2008;22:1459-62. http://dx.doi.org/10.1089/end.2008.0060

57. Szydelko T, Tuchendler T, Litarski A, et al. Laparoscopic Anderson-Hynes procedure as a treatment of ureteropelvic junction obstruction caused by fibroepithelial polyp. Wideochir Inne Tech Malo Inwazyine 2013;8:361-3. http://dx.doi.org/10.5114/wiitm.2011.35636

58. Takebayashi S, Hosaka M, Kubota Y, et al. Computerized tomographic ureteroscopy for diagnosing ureteral tumors. J Urol 2000;163:42-6. http://dx.doi.org/10.1016/S0022-5347(05)67968-2

59. Talja M, Salo J, Riihela M, et al. Fibroepithelial polyps of the ureter. Ann Chir Gynaecol 1991;80:307-10.

60. Tekdogan UY, Canakli F, Aslan Y, et al. Bilateral ureteral fibroepithelial polyps and review of the literature. Int J Urol 2005;12:98-100. http://dx.doi.org/10.1111/1.1442-2042.2004.00974.x

61. Terai A, Terachi T, Yoshida S. Prolapsed benign polyp of ureter associated with giant ureteral calculus. Hinyokika Kiyo 1989:35:871-3.

62. Toh KL, Cheng WS. Clinical cases: Flank pain. Case no 4. Techniques in Urology 1999;5:59.

63. Turunc T, Kuzgunbay B, Canpolat T. Ureteral fibroepithelial polyps with calculi: A case series. J Med Case Rep 2008;2:280. http://dx.doi.org/10.1186/1752-1947-2-280

64. Van Poppel H, Nuttin B, Oyen R, et al. Fibroepithelial polyps of the ureter. Etiology, diagnosis, treatment and pathology. Eur Urol 1986; 12:174-9.

65. Vogelzang RL, Calenoff L, Bulkley GJ. Ureteral intussusception caused by fibrous ureteral polyp. Urol Radiol 1981;3:47-9. http://dx.doi.org/10.1007/BF02938632

66. Wang ZJ, Meng MV, Yeh BM, et al. Ureteral fibroepithelial polyp. J Ultrasound Med 2008;27:1647-9.

67. Williams TR, Wagner BJ, Corse WR, et al. Fibroepithelial polyps of the urinary tract. Abdom Imaging 2002;27:217-21. http://dx.doi.org/10.1007/s00261-001-0066-z

68. $\mathrm{Xu} C$, Zhang Z, Ye H, et al. Imaging diagnosis and endoscopic treatment for ureteral fibroepithelial polyp prolapsing into the bladder. J Xray Sci Technol 2013;21:393-9.

69. Xu W, Yu CS, Yang L, et al. Ureteral intussusception due to a polyp. Abdom Imaging 2007;32:675-7. http://dx.doi.org/10.1007/s00261-006-9163-3

70. Yagi S, Kawano Y, Gotanda T, et al. Endoscopic treatment of a long fibroepithelial ureteral polyp. Int J Urol 2001;8:467-9. http://dx.doi.org/10.1046/j.1442-2042.2001.00343.x 
71. Ye L, Zhao L, Yue F, et al. Large ureteral fibroepithelial polyp lacking epithelium due to ischemic infarction. Kaohsiung J Med Sci 2012;28:457-61. http://dx.doi.org/10.1016/i.kjms.2012.02.018

72. Yeh CC, Lin $\mathrm{HC}$, Chen $C$, et al. Ureteral fibroepithelial polyp prolapsed into the bladder cavity suspending a bladder stone. J Urol 2001;165:1627-8. http://dx.doi.org/10.1016/S0022-5347 (05)66368-9

73. Zervas A, Rassidakis G, Nakopoulou L, et al. Transitional cell carcinoma arising from a fibroepithelial ureteral polyp in a patient with duplicated upper urinary tract. J Urol 1997;157:2252-3. http://dx.doi. org/10.1016/S0022-5347(01)64738-4

74. Zungri E, Algaba F, Santaularia JM, et al. Fibrous polyp of the ureter. Eur Urol 1981;7:215-9.

75. Isikay L, Ozdemir G, Altan $S A$, et al. A distal protruding ureteral polyp looking like a bladder mass. Urol Int 2002;69:323-4. http://dx.doi.org/10.1159/000066114

76. Ramanathan $R$, Kapoor $R$, Goel $M$, et al. Endourological management of a solitary upper ureteric fibroepithelial polyp: Snare resection technique. Indian I Urol 1996;12:51-3.

77. Tzeng WS, Wu RH, Huang SKH, et al. A comparison of pyelography and various reconstructions of multidetector helical computed tomography urography images for diagnosing urinary obstruction. Clin Imaging 2012;36:773-9. http://dx.doi.org/10.1016/i.clinimag.2011.11.015
78. Davides KC, King LM. Fibrous polyps of the ureter. J Urol 1976;115:651-3.

79. Adey GS, Vargas SO, Retick AB, et al. Fibroepithelial polyps causing ureteropelvic junction obstruction in children. J Urol 2003;169:1834-6. http://dx.doi.org/10.1097/01.ju.0000061966.21966.94

80. Niu ZB, Yang Y, Hou Y, et al. Ureteral polyps: An etiological factor of hydronephrosis in children that should not be ignored. Pediatr Surg Int 2007;23:323-6. http://dx.doi.org/10.1007/s00383-007-1884-z

81. Oguzkurt $P, 0 z S, 0$ guzkurt $L$, et al. An unusual cause of complete distal ureteral obstruction: Giant fibroepithelial polyp. J Pediatr Surg 2004;39:1733-4. htrp://dx.doi.org/10.1016/i.jpedsurg.2004.07.023

Correspondence: Dr. Dina J. Ludwig, Department of Urology, HagaZiekenhuis, The Hague, The Netherlands; hannaludwig@hotmail.com 